\title{
Racial Equality Frames and Public Policy Support: Survey Experimental Evidence
}

\author{
Micah English* $\quad$ Joshua L. Kalla ${ }^{\dagger}$
}

April 26, 2021

PRELIMINARY

\begin{abstract}
How do racial attitudes shape policy preferences in the era of Black Lives Matter and increasingly liberal views on racial issues? A large body of research finds that highlighting the benefits of progressive policies for racial minorities undermines support for those policies. However, Democratic elites have started centering race in their messaging on progressive public policies. To explore this puzzle, in this paper we offer an empirical test that examines the effect of describing an ostensibly race-neutral progressive policy with racial framing, as used by Democratic elites, on support for that policy. To benchmark these effects, we compare a race policy frame with class, class plus race, and neutral policy frames. We demonstrate that despite leftward shifts in public attitudes towards issues of racial equality, racial framing decreases support for race-neutral progressive policies. Generally, the class frame most successfully increases support for progressive policies across racial and political subgroups.
\end{abstract}

*Ph.D. Student, Department of Political Science, Yale University. micah.english@yale.edu, https://politi calscience.yale.edu/people/micah-english.

${ }^{\dagger}$ Assistant Professor, Department of Political Science and Department of Statistics and Data Science, Yale University. josh.kalla@yale.edu, https://joshuakalla.com 


\section{Introduction}

In American politics, the question is not whether racial attitudes matter, but rather how and why racial attitudes matter. Despite progress, racial prejudice continues to play a central role in American society, with devastating impacts for both racial minorities and white Americans.

What is the role of racial attitudes in shaping policy preferences? Although most white Americans agree with the general principles of racial equality, a large literature finds that white Americans remain reluctant to endorse policies that are designed to actually achieve racial equality. For example, racial priming tends to activate racial attitudes and decrease support for social welfare policies and policies perceived to aid Black Americans (for review, see Valenzuela and Reny 2020). While "old-fashioned racism" may have declined, "the turbulence of the late 1960s gave rise to a 'new racism' wherein opposition to policies designed to assist blacks was born out of a blend of traditional American moral values and anti-black affect" (Hutchings and Valentino 2004, p. 390). A large body of research thus finds that in some form, racism remains a pernicious force in white Americans' policy preferences.

Yet, in recent years, Democratic elites have started centering race in their messaging, even on topics not explicitly about race. Prominent Democratic pollsters and strategists argue that this is a way to both motivate the Democratic base and persuade voters. $]^{1}$ Recent research also suggests that white racial attitudes are shifting in a way that may have meaningful political ramifications, suggesting that explicit discussions of race could potentially be beneficial to racial equity causes (e.g., Sawyer and Gampa 2018, Jardina, Kalmoe and Gross 2020). This is surprising given how Republicans have historically used racialized language to decrease support for progressive policies (e.g., Hacker and Pierson 2020).

Are Democratic elites wise to explicitly use racial justice framing in promoting their ostensibly

${ }^{1}$ For example, https://www.politico.com/f/?id=00000175-b4b4-dc7f-a3fd-bdf660490000. 
“race-neutral" progressive policies $2^{2}$ Decades of political science research would suggest linking progressive policies with race would decrease support for those policies, particularly among white Americans. Yet, increasingly, Democratic elites are talking explicitly about race (see Table 1). Might Democratic elites' messaging strategies, particularly in light of the heightened salience of racial inequities in American society and growing antiracist social movements, reflect a meaningful shift in public opinion that has not yet been incorporated in political scientists' theorizing on the role of race in policy preferences?

To explore this question, we offer an empirical test that examines the effect of describing a policy with racial framing, as used by Democratic elites, on support for that policy. To benchmark these effects, we compare a race policy frame with class, class plus race and neutral policy frames. Specifically, we utilize an online survey experiment to test the impact of these various frames on six different ostensibly race-neutral progressive policy proposals. Broadly, our results are consistent with much of the existing research that shows many white Americans, and Republicans in particular, remain wary of endorsing policies explicitly aimed at achieving racial equity. Furthermore, we find that a class frame that speaks to the economic impacts of these policies is generally the most effective at increasing policy support across a wide range of demographic subgroups. In the following sections, we will outline the theoretical background, discuss the data and the results, and conclude.

\section{Do Racial Frames Now Boost Instead of Undermine Support?}

A large body of research finds that framing a progressive policy around race undermines support for this policy. This research largely argues that white prejudice against Blacks decreases

${ }^{2}$ We use this phrase to describe policies that are not explicitly about race even if one effect could be promoting racial equity.

${ }^{3}$ The class plus race condition is distinct from the Race-Class Narrative Project. See https://www. wemakethefuture.us/history-of-the-race-class-narrative for further details. 
support for social policies perceived to aid Blacks and other minority groups (e.g., Gilens 2009 , Jardina 2019). Prejudice and racial resentment have long been exploited, explicitly and implicitly by politicians, often with the goal of undermining support for these policies (Mendelberg 2001). Purportedly race-neutral policies are also impacted by racial attitudes. Studies have demonstrated that white racial attitudes can predict opinions on issues such as criminal justice, welfare, healthcare, and Social Security (e.g., Jardina|2019; Gilens|2009; Tesler|2016).

However, in recent years, white racial attitudes and identity politics may have shifted in unprecedented ways. Since the election of America's first Black president, there has been a renewed interest among political scientists in assessing the political influence of white identity (see especially Jardina 2019; Chudy, Piston and Shipper 2019; Tesler 2016). Black Lives Matter may have caused a significant shift in racial attitudes, causing both liberals and conservatives to hold more racially egalitarian views (Sawyer and Gampa 2018). Studies since the 2016 election of Donald Trump, whose political platform relied at least partially on activating white racial resentment (Jardina 2019), show evidence of driving a change in racial attitudes. Jardina, Kalmoe and Gross (2020) find that social disgust associated with Trump has led to broad declines in white identity strength, a pattern that has persisted. However, they note that the implications of this for policy support is unclear: "future work is needed to explore whether the decline in white identity spills over into other policy attitudes and political preferences" (15). Recently, Democratic elites have more explicitly embraced the use of race in their public messaging, even when discussing ostensibly race-neutral policies.

Much political science research would suggest that such language would likely backfire: given many American's negative views of racial minorities, explicitly linking a policy to racial minorities would result in a decrease in support for that policy, particularly among white Americans. However, more recent research, and Democratic elites own messaging, might suggest that among a significant number of Americans, their racial attitudes may lead to increased support for policies perceived to benefit Black Americans and other racial minorities. In this paper, we 
empirically test these competing predictions to determine the effect of progressive racial framing around ostensibly race-neutral policies on support for those policies.

Table 1: Example of Racial Messaging Used by Democratic Politicians to Advocate for Ostensibly Race-Neutral Policies

\begin{tabular}{|c|c|}
\hline Politician & Message \\
\hline Pres. Joe Biden & $\begin{array}{l}\text { "President Biden is calling on Congress to make a historic and } \\
\text { overdue investment in our roads, bridges, rail, ports, airports, and } \\
\text { transit systems... These investments will advance racial equity by } \\
\text { providing better jobs and better transportation options to underserved } \\
\text { communities." (https://www.whitehouse.gov/briefing-room/statements } \\
\text {-releases/2021/03/31/fact-sheet-the-american-jobs-plan/) }\end{array}$ \\
\hline Rep. Ayanna Pressley & $\begin{array}{l}\text { "Student loan cancellation is a matter of racial and economic justice } \\
\text { across our country... Black student borrowers are forced to borrow } \\
\text { more than their white peers and are five times more likely to default } \\
\text { on a student loan." (https://finance.yahoo.com/news/student-loan-can } \\
\text { cellation-democrat-ayanna-pressley-argues-205611285.html) }\end{array}$ \\
\hline Sen. Elizabeth Warren & $\begin{array}{l}\text { "Canceling } \$ 50,000 \text { in student loan debt is a matter of racial justice, it } \\
\text { is a matter of economic justice, it is a matter of generational justice." } \\
\text { (https://www.youtube.com/watch?v=53Cyr4vw49U) }\end{array}$ \\
\hline Rep. Barbara Lee & $\begin{array}{l}\text { "Black, brown, and low-income communities bear the brunt of pollution } \\
\text { and environmental degradation, accelerated by climate change... that's } \\
\text { why addressing climate change is not just an environmental issue, but } \\
\text { also an imperative to achieve racial and economic justice." (https://ww } \\
\text { w.thenation.com/article/archive/reparations-green-new-deal-aoc/) }\end{array}$ \\
\hline Sen. Bernie Sanders & $\begin{array}{l}\text { "Raising the minimum wage is not just about economic justice - } \\
\text { it is about racial justice. Nearly half of Black and Latino workers } \\
\text { in America make under } \$ 15 \text { an hour. We must end starvation } \\
\text { wages, and give } 32 \text { million Americans a raise by increasing the } \\
\text { minimum wage to } \$ 15 \text { an hour." (https://twitter.com/BernieSanders/stat } \\
\text { us/1362111385539383298) }\end{array}$ \\
\hline
\end{tabular}

\section{Data and Research Design}

We estimate the effects of race, class, and class plus race issue framing on support for progressive policy proposals with a large, pre-registered online survey experiment $(n=5,089) \bigsqcup^{4}$

${ }^{4}$ Pre-analysis plan: https://osf.io/9brk6/?view_only=162f9e301d2341e2ae101d0d2fd8f036 
The survey was conducted using the online survey vendor Lucid in Spring 2021. In order to be eligible to participate, survey respondents needed to provide their informed consent, pass two attention check questions, and answer a series of baseline demographic questions. These were all pre-treatment measures.

After completing these baseline measures, respondents were randomly assigned to read a randomly sampled policy proposal out of six potential options (increasing the minimum wage to \$15; forgiving \$50,000 in student loan debt; upzoning housing; the Green New Deal; Medicare for All; decriminalizing marijuana and erasing prior convictions). Within a given policy domain, respondents were then randomly assigned to read about this policy in a neutral, race, class, or a class plus race frame (see Table 2 for an example; full wording is in the Online Appendix).

In our experiment, "race" framing refers to framing that emphasizes the benefits a policy will have towards racial equity or towards a specific racial group. "Class" framing refers to framing that emphasizes the benefits a policy will have towards economic justice or towards a specific class group. And finally, "class plus race" framing uses both frames, emphasizing how a policy will promote both racial and economic justice. The neutral frame explains the details of the policy and makes no references to either racial or class groups.

To improve the external validity of these findings, we adapted the frames from real-world political sources. Many of the frames came from interviews and social media posts where Democratic politicians were talking about these issues or from Democratic messaging research firms. In all conditions, the policy was always introduced by noting that some Democrats support it, thereby holding constant partisan cues across all message frame conditions. The race, class, and class plus race frames also began with the same policy details as in the neutral condition.

After reading about the policy, we asked our main outcome measure: "Do you support or oppose this policy?" Respondents could select from a seven-point scale, ranging from "Strongly support" to "Strongly oppose." In an attempt to probe for mechanisms, we then asked four secondary outcome measures on seven-point agree-disagree scales: "A majority of Republican 
party voters are likely to support this policy," "A majority of Democratic party voters are likely to support this policy," "People like me will benefit from this policy," “This is a fair policy.'5 After answering these questions, respondents were then randomly assigned to read about a new policy. In that new policy, the message frame was randomly assigned independent of the prior message frame. This process was repeated for all six policy domains.

Table 2: Example Treatment Language: Housing Policy

Neutral: Some Democrats are proposing a housing affordability policy that would help ensure that every American has a place to live. The policy would allow for smaller, lower-cost homes like duplexes, townhouses, and garden apartments to be built in middle- and upper-class neighborhoods, and would build new nonprofit homes.

Race: Neutral frame, then... A century of housing and land use policies denied Black households access to homeownership and neighborhood opportunities offered to white households. These racially discriminatory housing policies have combined to profoundly disadvantage Black households, with lasting, intergenerational impact. These intergenerational impacts go a long way toward explaining the racial disparities we see today in wealth, income and educational outcomes for Black Americans. Democrats say that this is why promoting housing affordability will also promote racial justice.

Class: Neutral frame, then... Housing is the largest single expense for the average American, accounting for a third of their income. Many working-class, middle-class, and working poor Americans spend over half their pay on shelter. Twenty-one million American families - over a sixth of the United States - are considered cost-burdened, paying more for rent than they can afford. These families are paying so much in rent that they are considered at elevated risk of homelessness. Democrats say that this is why housing affordability will help to reduce economic inequality.

Class plus Race: Neutral frame, then... A century of housing and land use policies denied Black households access to homeownership and neighborhood opportunities offered to white households. These racially discriminatory housing policies have combined to profoundly disadvantage Black households, with lasting, intergenerational impact. These intergenerational impacts go a long way toward explaining the racial disparities we see today in wealth, income and educational outcomes for Black Americans. Additionally, housing is the largest single expense for the average American, accounting for a third of their income. Many working-class, middle-class, and working poor Americans spend over half their pay on shelter. Twenty-one million American families - over a sixth of the United States - are considered cost-burdened, paying more for rent than they can afford. Democrats say that this is why housing affordability is an economic and racial justice issue.

${ }^{5}$ Following our pre-analysis plan, we analyzed the fairness measure with all respondents. The personal benefit measure was limited to non-Hispanic white respondents only. The perception of Democratic (Republican) support measure was limited to Democratic (Republican) respondents. 
To estimate the effects of message framing on policy support and our secondary outcomes, we estimate the following linear regression:

$$
D V_{i k}=\beta_{0}+\beta_{1} \text { Race }_{i k}+\beta_{2} \text { Class }_{i k}+\beta_{3} \text { RaceClass }_{i k}+\boldsymbol{\beta}^{\prime} \boldsymbol{X}_{\boldsymbol{i}}+\alpha_{k}+\varepsilon_{i k},
$$

where $D V_{i k}$ is the outcome measure for respondent $i$ on policy $k$, Race, Class, and RaceClass are dummy variables coded as 1 if respondent $i$ was randomly assigned to read that frame on policy $k$ (the neutral frame is the base category), $\boldsymbol{X}_{\boldsymbol{i}}$ is a vector of pre-registered, pre-treatment covariates included to improve the precision of our treatment effect estimates, and $\alpha_{k}$ is a fixed-effect for the policy domain..$^{6}$ We use cluster-robust standard errors at the respondent level. As a robustness test, we subset our analysis to only the first policy that a respondent read; substantive results are unchanged (see Table A1, Model 2).

In the main text, we report results using survey weights calculated from the 2020 Cooperative Election Study (Schaffner, Ansolabehere and Luks 2021). We weight on race-by-education interactions, race-by-age interactions, gender, income, and region. Weights are calculated using entropy balancing (Hainmueller and $\mathrm{Xu}$ 2013). As we did not specify how we would calculate survey weights in our pre-analysis plan, in the online appendix, we separately report all of the unweighted sample average treatment effects.

\section{Results}

The main results are summarized in Figure 1. Overall, we find that the class frame weakly dominates both the race and class plus race frames. Despite observed increases in support for racial justice and Democratic elites' use of race and class plus race frames in their public messaging, we find no evidence that Americans are persuaded by these policy frames.

Among all participants and across all issues, compared to the neutral condition, we find that

${ }^{6}$ The pre-treatment covariates are listed in the Online Appendix. 
Figure 1: Treatment Effect Across All Issues and Respondents

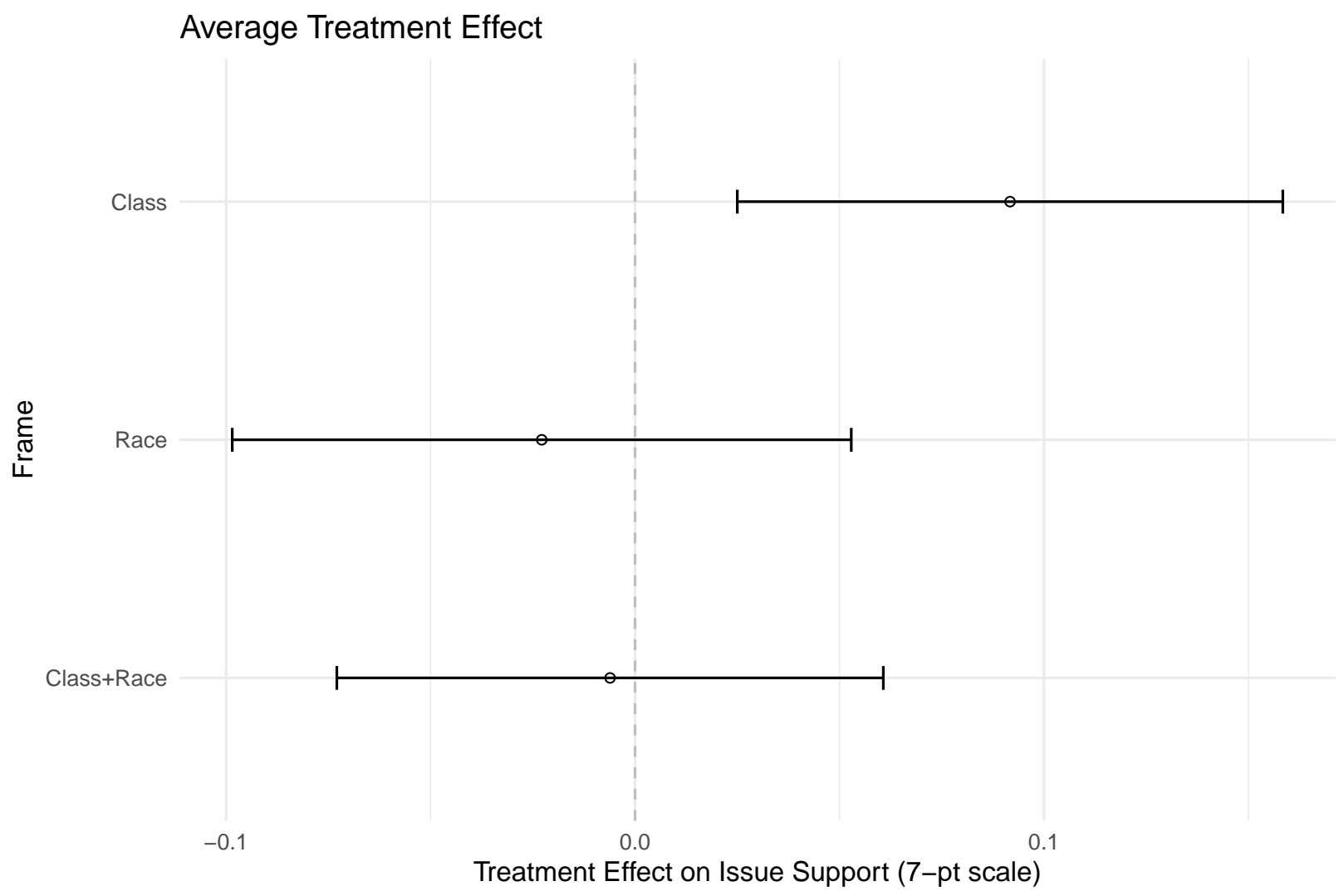

Notes: Error bars denote 95\% confidence intervals. Standard errors are clustered at the respondent level. Numerical results are available in Table A1.

the class frame increases policy support by a statistically significant 0.09 scale points on a sevenpoint scale relative to the neutral frame $(S E=0.03 ; p<0.01)$. To contextualize this effect, we can convert the seven-point scale into a binary measure of policy support, where any degree of support is coded as 1 while any degree of opposition or undecidedness is coded as 0 . On this binary measure, we find that the class frame increased policy support by a statistically significant 2.1 percentage points $(S E=0.9 ; p<0.05)$. On the other hand, neither the race nor the class plus race frames have any detectable effects on policy support. Interestingly, the null effect on the class plus race frame suggests that adding the race frame diminishes the positive effect of the class frame. 
However, this overall average treatment effect masks politically- and socially-relevant subgroup effects. For example, looking by respondent race, we first find that Black respondents are similarly responsive to both the class $(0.22$ scale points, $S E=0.10 ; p<0.05)$ and race frames $(0.19$ scale points, $S E=0.09 ; p<0.05)$. Black respondents are no more responsive to the race framing than they are to the class framing. On the other hand, non-Hispanic whites appear to be responsive to the class frame ( 0.09 scale points, $S E=0.04 ; p<0.05)$ while the race and class plus race frames cause negative, but not statistically significant, decreases in policy support. Among other racial subgroups, we do not detect statistically significant effects from any frame, which may partially be explained by small sample sizes. These results are summarized in Figure 2.

Next, in Figure 3, we present treatment effects by respondent partisanship. While among Democrats both the class and the class plus race frames cause statistically significant increases in policy support (and statistically indistinguishable from each other), among Republicans the class plus race frame causes a statistically significant decrease in policy support. While the race frame also has a negative effect among Republicans, it is not statistically significant. To again contextualize these effects in terms of binary policy support, we find that the class plus race frame decreases Republican support for a policy by 3.0 percentage points $(S E=1.3 ; p<0.05)$ and the race frame decreases Republican support by 1.9 percentage points $(S E=1.4 ; p=0.18)$. Finally, among Independents, we find positive effects from the class frame and negative effects from both the race and class plus race frames, but none of these effects are statistically significant.

Finally, in Figure 4 we examine treatment effect heterogeneity by respondent race and partisanship. Given limited sample sizes, we divide our sample into non-Hispanic white Democrats, non-Hispanic white Republicans, non-Hispanic white Independents, all non-white Democrats, all non-white Republicans, and all non-white Independents.7 Notably, among white Democrats, we find a statistically significant increase in policy support from the class frame $(0.13$

${ }^{7}$ We did not pre-register this subgroup. 
Figure 2: Treatment Effect Across All Issues, by Respondent Race

\section{Treatment Effect by Race}

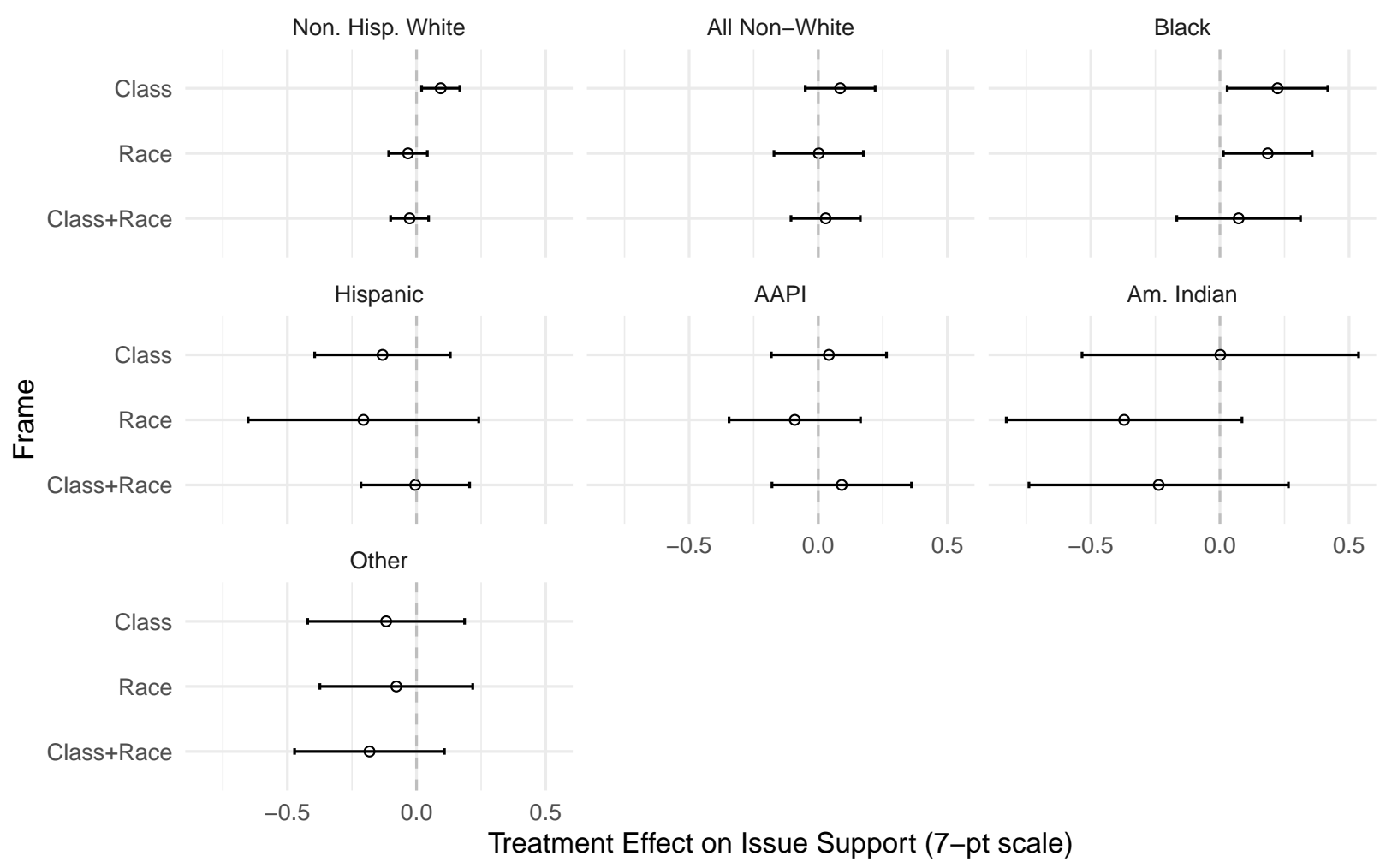

Notes: Error bars denote 95\% confidence intervals. Standard errors are clustered at the respondent level. Numerical results are available in Table A4.

scale points, $S E=0.05 ; p<0.01)$ while among white Republicans, we find a statistically significant decrease in policy support from the class plus race frame $(-0.14$ scale points, $S E=0.06 ; p<0.05)$. While not statistically significant, we also find an increase in policy support from the class frame and a decrease from the race frame among white Republicans. There is no evidence that white Democrats are particularly responsive to the race frames. Similarly, among non-white Democrats, the effects of the three frames are similar: 0.06 scale points from the class frame $(S E=0.07 ; p=0.39), 0.06$ scale points from the race frame $(S E=0.07 ; p=0.34)$, and 0.12 scale points from the class plus race frame $(S E=0.07 ; p<0.1)$. None of the differences between these frames are statistically significant. 
Figure 3: Treatment Effect Across All Issues, by Respondent Partisanship

Treatment Effect by Partisanship

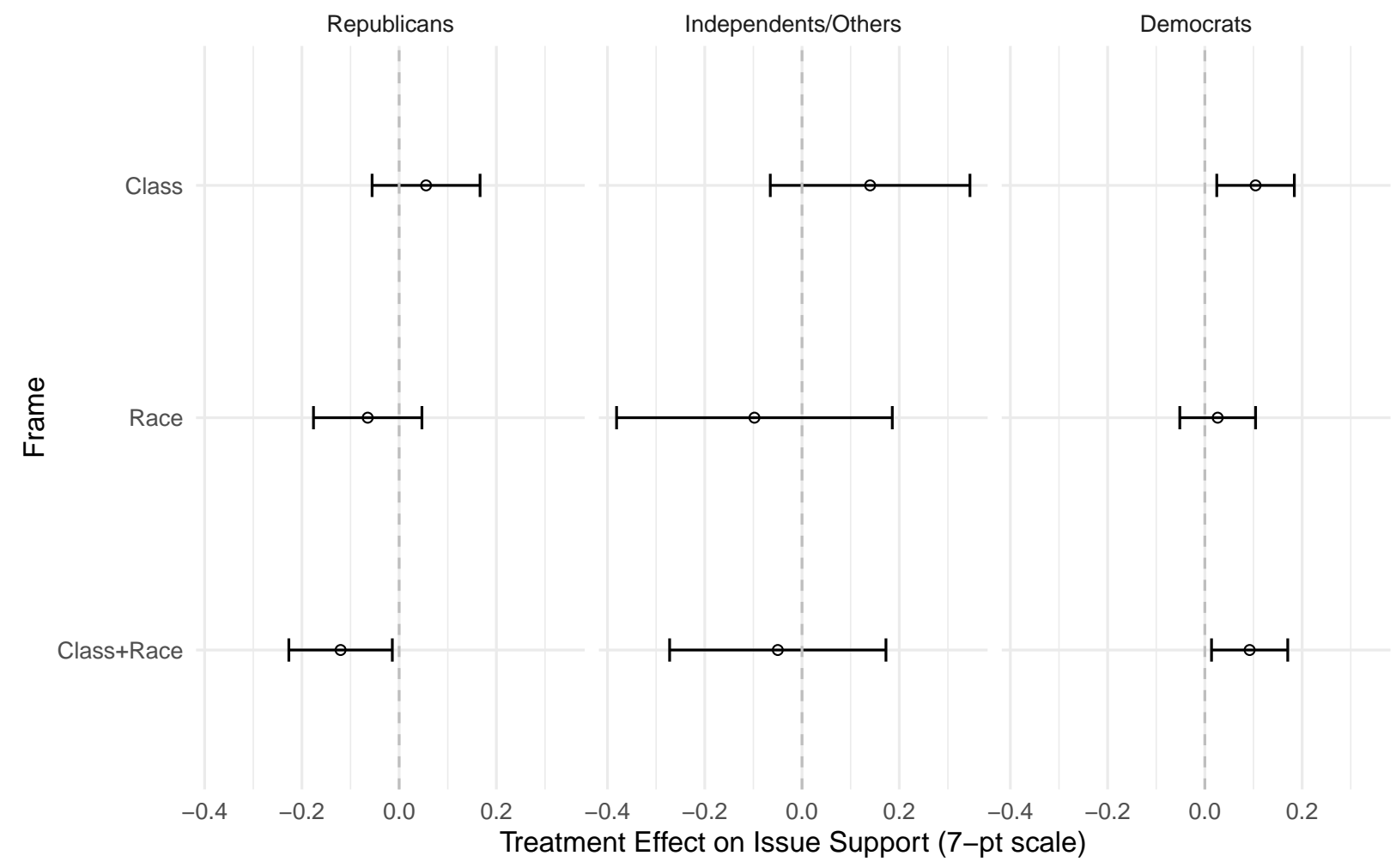

Notes: Error bars denote 95\% confidence intervals. Standard errors are clustered at the respondent level. Numerical results are available in Table A3

In Tables A10 A12 we also report subgroup effects by self-reported class and terciles of the collective guilt index among white respondents (Chudy, Piston and Shipper 2019). Both race framing conditions decrease support among those respondents with the least amount of guilt while the class framing is most effective at increasing support with those in the middle. Respondents with the most guilt are already overwhelmingly supportive of these policies.

Overall, we find no evidence that racial framing increases policy support. Among those subgroups (Democrats, racial minorities) who might be expected to be responsive to racial framing, we find no differences between race and class framing. However, among Republicans, we generally find evidence of backlash from race framing. 
Figure 4: Treatment Effect Across All Issues, by Respondent Race and Partisanship

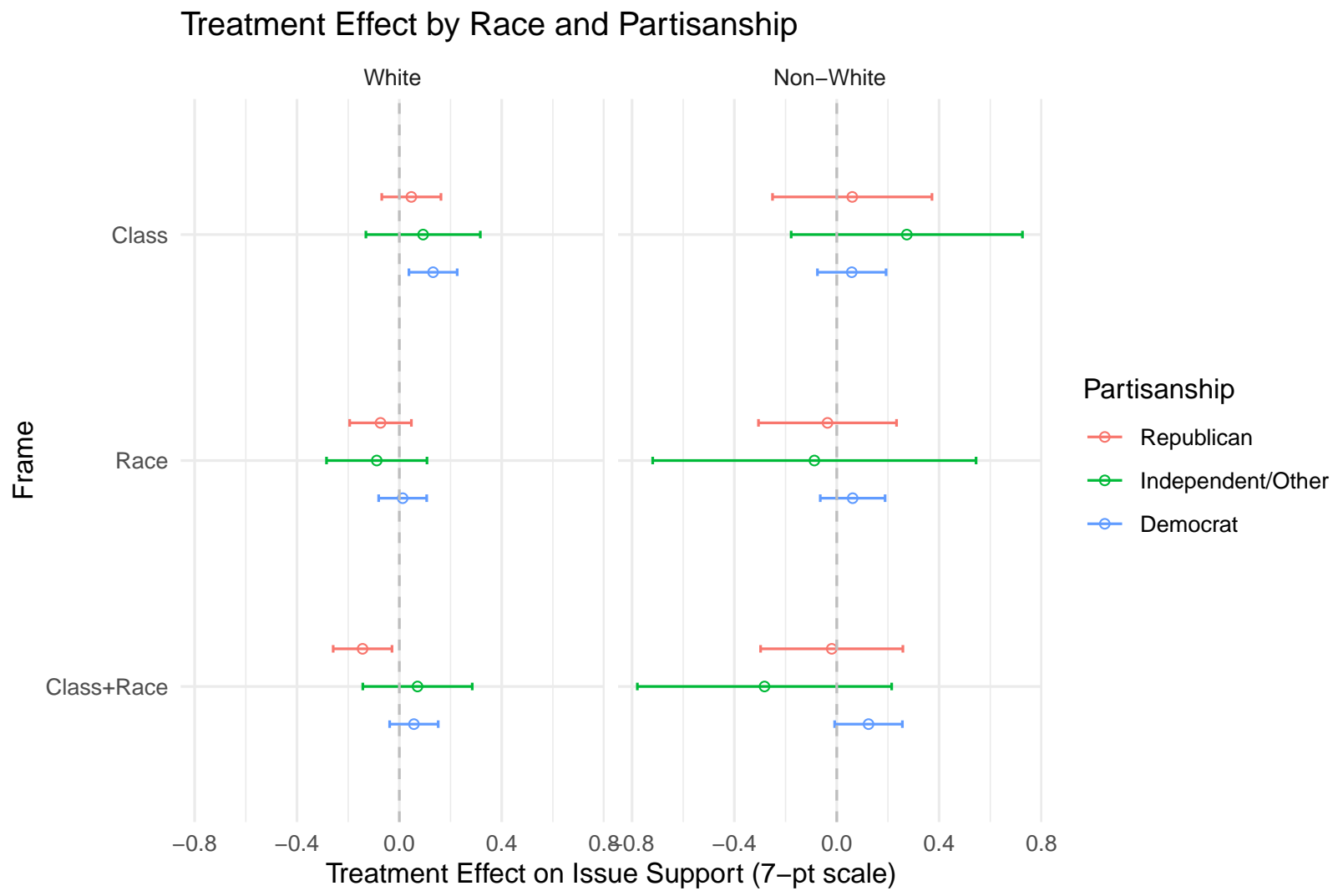

Notes: Error bars denote 95\% confidence intervals. Standard errors are clustered at the respondent level. Numerical results are available in Table A6.

In an attempt to explain the mechanisms behind these results, Table A9 presents effects on our secondary outcomes. First, among white respondents, we find that the class frame significantly increases their belief that "People like me will benefit from this policy" by 0.14 scale points $(S E=$ $0.04 ; p<0.01)$. On a binary measure, this is the equivalent of a 3.0 percentage point increase $(S E=1.0 ; p<0.01)$. The class frame is better able to communicate to white respondents that they personally will benefit from these policies. We see no effect of the other frames.

Second, we find that the class frame also significantly increases all respondents' likelihood of agreeing that "This is a fair policy" by 0.08 scale points $(S E=0.04 ; p<0.05)$. On a binary scale, this is equivalent to a 1.6 percentage point increase in perception of fairness $(S E=1.0 ; p<0.1)$. 
On the other hand, both the race and class plus race frames decrease this perception of fairness, although the effects are not statistically significant.

Finally, we find marginally statistically significant evidence that the class frame shifts Republican respondents' second-order beliefs about who supports these policies. Republican respondents in the class frame condition were 0.08 scale points more likely to agree that "A majority of Republican party voters are likely to support this policy" ( $S E=0.05 ; p<0.1$ ). On a binary measure of agreement, we find that the class frame increases these second-order beliefs by 1.8 percentage points $(S E=1.14 ; p=0.11)$. However, we find that none of the frames have any effect on Democratic respondents' second-order beliefs about Democratic voters.

\section{Conclusion}

As we have demonstrated, despite leftward shifts in public attitudes towards issues of racial equality, racial framing generally decreases support for progressive policies. Despite increasing awareness of racial inequities and a greater use of progressive race framing by Democratic elites, linking public policies to race is detrimental for support of those policies. Importantly, our results showed that Black Americans were just as swayed by the class frame as they were the race frame. Future research should investigate the causal mechanisms behind this.

As Mendelberg (2001, p. 187) detailed in her examination of racial appeals:

Democrats are correct in perceiving that their best interests lie in shifting the electoral agenda away from race and toward economic issues on which blacks and workingclass whites can agree. The Democrats can still pursue racially liberal policies while in office, and in fact it is in their interest to do so. By eroding racial inequality they will aid in bridging the racial divide that renders them so electorally vulnerable. But as many African Americans recognize, highlighting these efforts to white voters is likely to erode Democratic support among whites.

It appears that this still holds true today. Democrats' use of racial frames in describing their 
progressive policies may inadvertently make it harder for them to adopt public policies that will advance racial justice.

\section{References}

Chudy, Jennifer, Spencer Piston and Joshua Shipper. 2019. "Guilt by association: White collective guilt in American politics.” The Journal of Politics 81(3):968-981.

Gilens, Martin. 2009. Why Americans hate welfare: Race, media, and the politics of antipoverty policy. University of Chicago Press.

Hacker, Jacob S and Paul Pierson. 2020. Let Them Eat Tweets: How the Right Rules in an Age of Extreme Inequality. Liveright Publishing.

Hainmueller, Jens and Yiqing Xu. 2013. "Ebalance: A Stata package for entropy balancing." Journal of Statistical Software 54(7).

Hutchings, Vincent L and Nicholas A Valentino. 2004. "The centrality of race in American politics.” Annu. Rev. Polit. Sci. 7:383-408.

Jardina, Ashley. 2019. White identity politics. Cambridge University Press.

Jardina, Ashley, Nathan Kalmoe and Kimberly Gross. 2020. "Disavowing White Identity: How Social Disgust can Change Social Identities.” Political Psychology .

Mendelberg, Tali. 2001. The race card: Campaign strategy, implicit messages, and the norm of equality. Princeton University Press.

Sawyer, Jeremy and Anup Gampa. 2018. "Implicit and explicit racial attitudes changed during Black Lives Matter.” Personality and Social Psychology Bulletin 44(7):1039-1059.

Schaffner, Brian, Stephen Ansolabehere and Sam Luks. 2021. "Cooperative Election Study Common Content, 2020.”. 
Tesler, Michael. 2016. Post-racial or most-racial?: Race and politics in the Obama era. University of Chicago Press.

Valenzuela, Ali A and Tyler T Reny. 2020. Evolution of Experiments on Racial Priming. Cambridge University Press New York, NY chapter 24, pp. 447-467. 


\section{Online Appendix}

\section{A Ethical Standards}

The authors declare that the human subjects research in this article was reviewed and approved by the REDACTED University Human Subjects Committee. The authors affirm that this article adheres to the APSA's Principles and Guidance on Human Subjects Research. Participants were compensated for their participation by the panel provider.

\section{B List of Pre-Treatment Covariates}

The pre-treatment covariates are (from the survey) class, ideology, Biden approval, 2020 vote choice, partisanship, generic House vote, political knowledge about House control, political knowledge about Attorney General, political knowledge about Dodd Frank, political knowledge about breaking Senate ties, (from Lucid) age, gender, household income, ethnicity, education, partisanship, and region. These were all specified in the pre-analysis plan.

\section{Treatment Wording Minimum Wage}

- Neutral: Congress has not increased the federal minimum wage, currently set at $\$ 7.25$, since 2009. Some Democrats are proposing a policy that would gradually raise the federal minimum wage to $\$ 15$ an hour by 2025 . After 2025 , the minimum wage would be adjusted each year to keep pace with growth in the median wage, a measure of wages for typical workers.

- Race: Congress has not increased the federal minimum wage, currently set at $\$ 7.25$, since 2009. Some Democrats are proposing a policy that would gradually raise the federal minimum wage to $\$ 15$ an hour by 2025 . After 2025 , the minimum wage would be adjusted each year to keep pace with growth in the median wage, a measure of wages for typical workers. Democrats say that a minimum wage increase would boost incomes for people of color, especially women of color, who make up a disproportionate share of low-wage workers. This is why Democrats say that raising the minimum wage would be an effective tool for racial justice.

- Class: Congress has not increased the federal minimum wage, currently set at $\$ 7.25$, since 2009. Some Democrats are proposing a policy that would gradually raise the federal minimum wage to $\$ 15$ an hour by 2025 . After 2025 , the minimum wage would be adjusted each year to keep pace with growth in the median wage, a measure of wages for typical workers. Democrats say that low wages hurt all workers, especially those with lower-income levels, and that a minimum wage increase would lift nearly a million people out of poverty. This is why Democrats say that raising the minimum wage would be an effective tool for economic justice. 
- Class+Race: Congress has not increased the federal minimum wage, currently set at $\$ 7.25$, since 2009. Some Democrats are proposing a policy that would gradually raise the federal minimum wage to $\$ 15$ an hour by 2025 . After 2025 , the minimum wage would be adjusted each year to keep pace with growth in the median wage, a measure of wages for typical workers. Democrats say that a minimum wage increase would boost incomes for people of color, especially women of color, who make up a disproportionate share of low-wage workers. They also say that low wages hurt all workers, especially those with lower-income levels, and that a minimum wage increase would lift nearly a million people-Black, brown, and white- out of poverty. This is why Democrats say that raising the minimum wage would be an effective tool for racial and economic justice.

\section{Student Loan Debt}

- Neutral: Some Democrats are proposing a policy that would help to address the student loan debt crisis by forgiving up to $\$ 50,000$ in loans per borrower. Approximately 42 million Americans, or about 1 in 6 American adults, owe a cumulative \$1.6 trillion in student loans. Student loans are now the second-largest slice of household debt after mortgages, bigger than credit card debt.

- Race: Some Democrats are proposing a policy that would help to address the student loan debt crisis by forgiving up to $\$ 50,000$ in loans per borrower. Approximately 42 million Americans, or about 1 in 6 American adults, owe a cumulative $\$ 1.6$ trillion in student loans. Student loans are now the second-largest slice of household debt after mortgages, bigger than credit card debt. Democrats say that college shouldn't just be a privilege for those who can afford to take on the significant expenses associated with higher education. Numerous studies have shown that student loan debt disproportionately impacts communities of color, and Black people in particular. Black college students are more likely to rely on student debt to attend college and, because of factors like employment discrimination and disparities in wealth accumulation, they typically owe more than they originally borrowed, even after many years of repayment. This is why Democrats say that this policy will help to promote racial justice.

- Class: Some Democrats are proposing a policy that would help to address the student loan debt crisis by forgiving up to $\$ 50,000$ in loans per borrower. Approximately 42 million Americans, or about 1 in 6 American adults, owe a cumulative \$1.6 trillion in student loans. Student loans are now the second-largest slice of household debt after mortgages, bigger than credit card debt. Democrats say that college shouldn't just be a privilege for those who can afford to take on the significant expenses associated with higher education. They say that the enormous student debt burden weighing down our economy isn't the result of laziness or irresponsibility, but that it is the result of a government that has consistently put the interests of the wealthy and well-connected over the interests of working families. This plan would

help millions of lower-income and middle-class families, which is why Democrats say that this policy will help to promote economic justice. 
- Class+Race: Some Democrats are proposing a policy that would help to address the student loan debt crisis by forgiving up to $\$ 50,000$ in loans per borrower. Approximately 42 million Americans, or about 1 in 6 American adults, owe a cumulative $\$ 1.6$ trillion in student loans. Student loans are now the second-largest slice of household debt after mortgages, bigger than credit card debt. Democrats say that college shouldn't just be a privilege for those who can afford to take on the significant expenses associated with higher education. Numerous studies have shown that student loan debt disproportionately impacts communities of color, and Black people in particular. Black college students are more likely to rely on student debt to attend college and, because of factors like employment discrimination and disparities in wealth accumulation, they typically owe more than they originally borrowed, even after many years of repayment. Democrats also say that the enormous student debt burden weighing down our economy isn't the result of laziness or irresponsibility, but that it is the result of a government that has consistently put the interests of the wealthy and well-connected over the interests of working families. This plan would help millions of lower-income and middle-class families, including but not only families of color, which is why Democrats say that this policy will help to promote racial and economic justice.

\section{Housing Policy}

- Neutral: Some Democrats are proposing a housing affordability policy that would help ensure that every American has a place to live. The policy would allow for smaller, lowercost homes like duplexes, townhouses, and garden apartments to be built in middle- and upper-class neighborhoods, and would build new nonprofit homes.

- Race: Some Democrats are proposing a housing affordability policy that would help ensure that every American has a place to live. The policy would allow for smaller, lower-cost homes like duplexes, townhouses, and garden apartments to be built in middle- and upper-class neighborhoods, and would build new nonprofit homes. A century of housing and land use policies denied Black households access to homeownership and neighborhood opportunities offered to white households. These racially discriminatory housing policies have combined to profoundly disadvantage Black households, with lasting, intergenerational impact. These intergenerational impacts go a long way toward explaining the racial disparities we see today in wealth, income and educational outcomes for Black Americans. Democrats say that this is why promoting housing affordability will also promote racial justice.

- Class: Some Democrats are proposing a housing affordability policy that would help ensure that every American has a place to live. The policy would allow for smaller, lower-cost homes like duplexes, townhouses, and garden apartments to be built in middleand upper-class neighborhoods, and would build new nonprofit homes. Housing is the largest single expense for the average American, accounting for a third of their income. Many working-class, middle-class, and working poor Americans spend over half their pay on shelter. Twenty-one million American families - over a sixth of the United States - are 
considered cost-burdened, paying more for rent than they can afford. These families are paying so much in rent that they are considered at elevated risk of homelessness. Democrats say that this is why housing affordability will help to reduce economic inequality.

- Class+Race: Some Democrats are proposing a housing affordability policy that would help ensure that every American has a place to live. The policy would allow for smaller, lower-cost homes like duplexes, townhouses, and garden apartments to be built in middleand upper-class neighborhoods, and would build new nonprofit homes. A century of housing and land use policies denied Black households access to homeownership and neighborhood opportunities offered to white households. These racially discriminatory housing policies have combined to profoundly disadvantage Black households, with lasting, intergenerational impact. These intergenerational impacts go a long way toward explaining the racial disparities we see today in wealth, income and educational outcomes for Black Americans. Additionally, housing is the largest single expense for the average American, accounting for a third of their income. Many working-class, middle-class, and working poor Americans spend over half their pay on shelter. Twenty-one million American families - over a sixth of the United States - are considered cost-burdened, paying more for rent than they can afford. Democrats say that this is why housing affordability is an economic and racial justice issue.

\section{Climate Policy}

- Neutral: Some Democrats are proposing a Green New Deal bill which would phase out the use of fossil fuels, with the government providing clean energy jobs for people who can't find employment in the private sector. All jobs would pay at least $\$ 15$ an hour, and include healthcare benefits and collective bargaining rights. This would be paid for by raising taxes on incomes over $\$ 200,000$ dollars a year by 15 percentage points.

- Race: Some Democrats are proposing a Green New Deal bill which would phase out the use of fossil fuels, with the government providing clean energy jobs for people who can't find employment in the private sector. All jobs would pay at least $\$ 15$ an hour, and include healthcare benefits and collective bargaining rights. This would be paid for by raising taxes on incomes over $\$ 200,000$ dollars a year by 15 percentage points. Black and brown communities bear the brunt of pollution and environmental degradation, accelerated by climate change. Democrats say that's why addressing climate change is not just an environmental issue, but also an imperative to achieve racial justice.

- Class: Some Democrats are proposing a Green New Deal bill which would phase out the use of fossil fuels, with the government providing clean energy jobs for people who can't find employment in the private sector. All jobs would pay at least $\$ 15$ an hour, and include healthcare benefits and collective bargaining rights. This would be paid for by raising taxes on incomes over $\$ 200,000$ dollars a year by 15 percentage points. Democrats say this would improve the economy by giving people jobs, fighting climate change and reducing pollution in the air and water. They also say that a proposal like this could create over 10 million green 
new jobs. Democrats say that's why addressing climate change is not just an environmental issue, but also an imperative to achieve economic justice.

- Class+Race: Some Democrats are proposing a Green New Deal bill which would phase out the use of fossil fuels, with the government providing clean energy jobs for people who can't find employment in the private sector. All jobs would pay at least \$15 an hour, and include healthcare benefits and collective bargaining rights. This would be paid for by raising taxes on incomes over $\$ 200,000$ dollars a year by 15 percentage points. Democrats say that lowincome Black, brown, and white communities bear the brunt of pollution and environmental degradation, accelerated by climate change. Democrats say this plan would improve the economy for everyone by giving people jobs, fighting climate change and reducing pollution in the air and water. They also say that a proposal like this could create over 10 million green new jobs. Democrats say that's why addressing climate change is not just an environmental issue, but also an imperative to achieve racial and economic justice.

\section{Medicare for All}

- Neutral: Some Democrats in Congress are proposing a bill which would expand Medicare to every American, with the government providing health insurance to every American citizen. All out of pocket costs such as copays and premiums would be eliminated. This policy would change Americans' insurance provider but would not prevent them from accessing medical services already available to them under their current plan. Individuals could supplement the public plan with a private option if they wanted.

- Race: Some Democrats in Congress are proposing a bill which would expand Medicare to every American, with the government providing health insurance to every American citizen. All out of pocket costs such as copays and premiums would be eliminated. This policy would change Americans' insurance provider but would not prevent them from accessing medical services already available to them under their current plan. Individuals could supplement the public plan with a private option if they wanted. Universal health care is a racial justice necessity because communities of color, in particular, suffer from a lack of access to affordable health insurance. Democrats say that this policy ensures that everyone in America has access to quality healthcare, no matter their race.

- Class: Some Democrats in Congress are proposing a bill which would expand Medicare to every American, with the government providing health insurance to every American citizen. All out of pocket costs such as copays and premiums would be eliminated. This policy would change Americans' insurance provider but would not prevent them from accessing medical services already available to them under their current plan. Individuals could supplement the public plan with a private option if they wanted. One in five working-age Americans report having problems paying their medical bills despite having health insurance, driven by expensive premiums, copays and deductibles. Democrats say that this policy ensures that everyone in America has access to quality healthcare, no matter their income. 
- Class+Race: Some Democrats in Congress are proposing a bill which would expand Medicare to every American, with the government providing health insurance to every American citizen. All out of pocket costs such as copays and premiums would be eliminated. This policy would change Americans' insurance provider but would not prevent them from accessing medical services already available to them under their current plan. Individuals could supplement the public plan with a private option if they wanted. One in five working-age Americans report having problems paying their medical bills despite having health insurance, driven by expensive premiums, copays and deductibles. Universal health care is also a racial justice necessity because communities of color, in particular, suffer from a lack of access to affordable health insurance. Democrats say that this policy ensures that everyone in America has access to quality healthcare, no matter their income or race.

\section{Marijuana Reform}

- Neutral: Some Democrats in Congress are proposing a bill which would lead to comprehensive marijuana reform legislation. It would help rebuild communities that have been the most impacted by marijuana criminalization under federal law. It would also remove marijuana from the federal list of banned substances, allowing states to set their own marijuana policies. It would also create pathways to erase previous convictions and prohibit discrimination based on the use or possession of marijuana.

- Race: Some Democrats in Congress are proposing a bill which would lead to comprehensive marijuana reform legislation. It would help rebuild communities that have been the most impacted by marijuana criminalization under federal law. It would also remove marijuana from the federal list of banned substances, allowing states to set their own marijuana policies. It would also create pathways to erase previous convictions and prohibit discrimination based on the use or possession of marijuana. Law enforcement agencies arrest hundreds of thousands of people for marijuana possession every year, and in every state Black people are far more likely to be arrested than white people, although they use marijuana at similar rates. Democrats say that is why comprehensive marijuana reform is a racial justice issue that would help address the historic, intergenerational harms wrought by decades of racially disparate enforcement.

- Class: Some Democrats in Congress are proposing a bill which would lead to comprehensive marijuana reform legislation. It would help rebuild communities that have been the most impacted by marijuana criminalization under federal law. It would also remove marijuana from the federal list of banned substances, allowing states to set their own marijuana policies. It would also create pathways to erase previous convictions and prohibit discrimination based on the use or possession of marijuana. People with marijuana-related convictions can lose their housing, employment, and federal benefits. Some states that have legalized marijuana prevent people with drug convictions from participating in the emerging marketplace, ensuring that those harmed most by marijuana prohibition are cut off from the profits and employment that legalization can bring. Democrats say that's why comprehensive marijuana reform is an economic justice issue. 
- Class+Race: Some Democrats in Congress are proposing a bill which would lead to comprehensive marijuana reform legislation. It would help rebuild communities that have been the most impacted by marijuana criminalization under federal law. It would also remove marijuana from the federal list of banned substances, allowing states to set their own marijuana policies. It would also create pathways to erase previous convictions and prohibit discrimination based on the use or possession of marijuana. Law enforcement agencies arrest hundreds of thousands of people for marijuana possession every year, and in every state Black people are far more likely to be arrested than white people, although they use marijuana at similar rates. People with marijuana-related convictions can lose their housing, employment, and federal benefits. Some states that have legalized marijuana prevent people with drug convictions from participating in the emerging marketplace, ensuring that those harmed most by marijuana prohibition are cut off from the profits and employment that legalization can bring. Democrats say that's why comprehensive marijuana reform is a racial and economic justice issue that would help to support the communities most harmed by punitive drug policy.

\section{Additional Tables and Results}




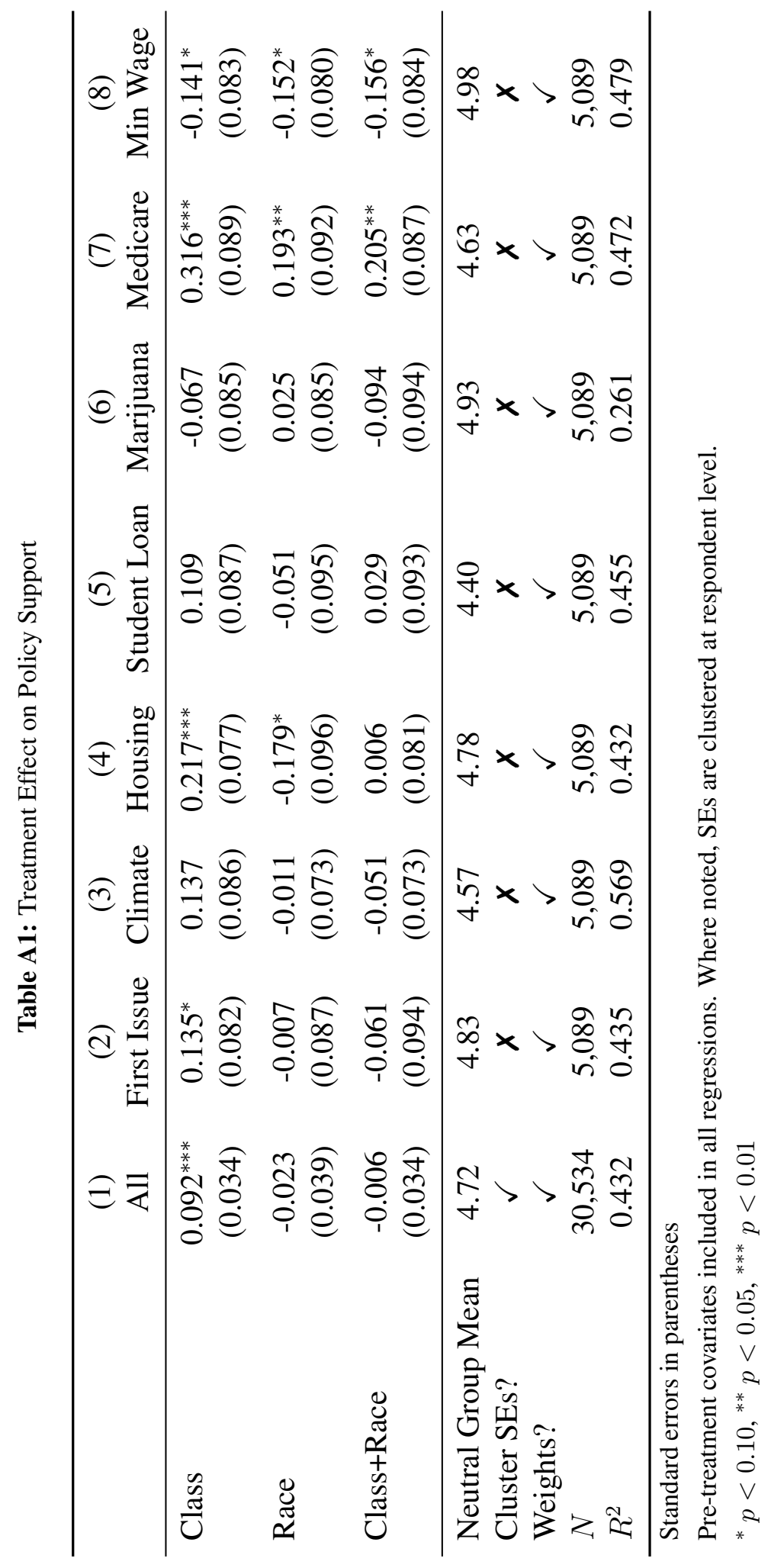




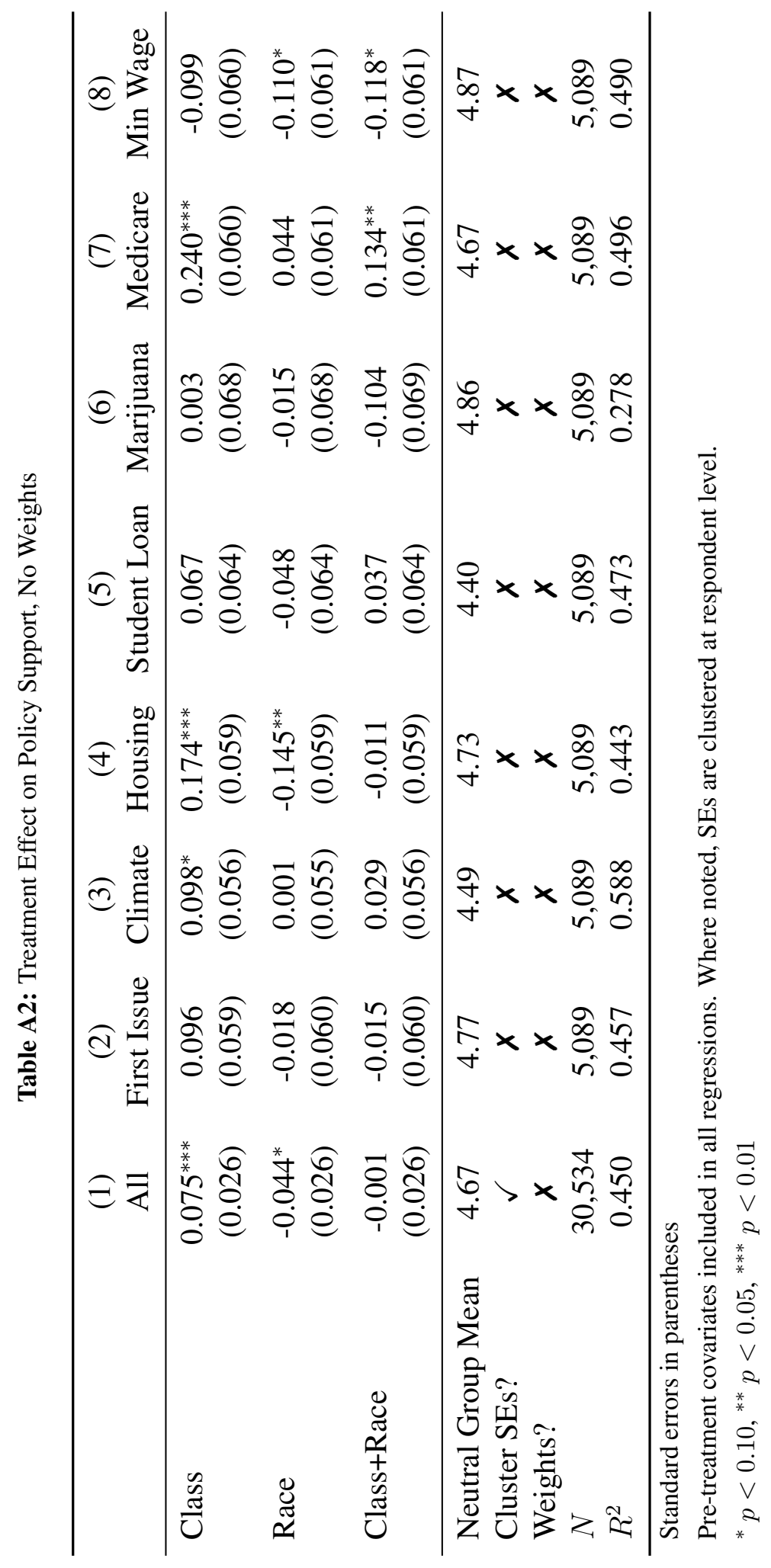


Table A3: Treatment Effect on Policy Support by Partisanship

\begin{tabular}{lcccccc}
\hline & $(1)$ & $(2)$ & $(3)$ & $(4)$ & $(5)$ & $(6)$ \\
& Democrats & Democrats & Republicans & Republicans & Indep/Other & Indep/Other \\
\hline Class & $0.065^{* *}$ & $0.104^{* *}$ & 0.040 & 0.055 & $0.209^{* * *}$ & 0.140 \\
& $(0.032)$ & $(0.041)$ & $(0.047)$ & $(0.057)$ & $(0.074)$ & $(0.105)$ \\
Race & -0.008 & 0.026 & $-0.100^{* *}$ & -0.065 & -0.010 & -0.098 \\
& $(0.032)$ & $(0.040)$ & $(0.046)$ & $(0.057)$ & $(0.072)$ & $(0.145)$ \\
Class+Race & $0.057^{*}$ & $0.092^{* *}$ & $-0.099^{* *}$ & $-0.120^{* *}$ & 0.035 & -0.050 \\
& $(0.032)$ & $(0.040)$ & $(0.046)$ & $(0.054)$ & $(0.074)$ & $(0.113)$ \\
\hline Neutral Group Mean & 5.80 & 5.78 & 3.36 & 3.44 & 4.31 & 4.50 \\
Cluster SEs? & $\checkmark$ & $\checkmark$ & $\checkmark$ & $\checkmark$ & $\checkmark$ & $\checkmark$ \\
Weights? & $\boldsymbol{X}$ & $\checkmark$ & $\boldsymbol{X}$ & $\checkmark$ & $\boldsymbol{X}$ & $\checkmark$ \\
$N$ & 14,598 & 14,598 & 11,466 & 11,466 & 4,470 & 4,470 \\
$R^{2}$ & 0.141 & 0.149 & 0.332 & 0.336 & 0.257 & 0.230 \\
\hline
\end{tabular}

Standard errors in parentheses

Pre-treatment covariates included in all regressions.

Where noted, SEs are clustered at respondent level.

${ }^{*} p<0.10,{ }^{* *} p<0.05,{ }^{* * *} p<0.01$ 
Table A4: Treatment Effect on Policy Support by Race

\begin{tabular}{lcccccc}
\hline & $(1)$ & $(2)$ & $(3)$ & $(4)$ & $(5)$ & $(6)$ \\
& Non-Hisp White & Black & Am Indian & AAPI & Hispanic & Other \\
\hline Class & $0.094^{* *}$ & $0.223^{* *}$ & 0.001 & 0.041 & -0.132 & -0.118 \\
& $(0.038)$ & $(0.099)$ & $(0.273)$ & $(0.114)$ & $(0.134)$ & $(0.155)$ \\
Race & -0.033 & $0.185^{* *}$ & -0.371 & -0.091 & -0.206 & -0.078 \\
& $(0.038)$ & $(0.088)$ & $(0.233)$ & $(0.130)$ & $(0.228)$ & $(0.151)$ \\
Class+Race & -0.027 & 0.072 & -0.237 & 0.091 & -0.005 & -0.182 \\
& $(0.038)$ & $(0.122)$ & $(0.256)$ & $(0.138)$ & $(0.107)$ & $(0.148)$ \\
\hline Neutral Group Mean & 4.48 & 5.64 & 4.87 & 4.69 & 5.17 & 4.69 \\
Cluster SEs? & $\checkmark$ & $\checkmark$ & $\checkmark$ & $\checkmark$ & $\checkmark$ & $\checkmark$ \\
Weights? & $\checkmark$ & $\checkmark$ & $\checkmark$ & $\checkmark$ & $\checkmark$ & $\checkmark$ \\
$N$ & 23,052 & 2,622 & 390 & 1,572 & 1,824 & 1,074 \\
$R^{2}$ & 0.443 & 0.193 & 0.574 & 0.383 & 0.409 & 0.447 \\
\hline
\end{tabular}

Standard errors in parentheses

Pre-treatment covariates included in all regressions. Where noted, SEs are clustered at respondent level.

${ }^{*} p<0.10,{ }^{* *} p<0.05,{ }^{* * *} p<0.01$

Table A5: Treatment Effect on Policy Support by Race, No Weights

\begin{tabular}{|c|c|c|c|c|c|c|}
\hline & $\begin{array}{c}(1) \\
\text { Non-Hisp White }\end{array}$ & $\begin{array}{l}(2) \\
\text { Black }\end{array}$ & $\begin{array}{c}(3) \\
\text { Am Indian }\end{array}$ & $\begin{array}{c}(4) \\
\text { AAPI }\end{array}$ & $\begin{array}{c}(5) \\
\text { Hispanic }\end{array}$ & $\begin{array}{l}(6) \\
\text { Other }\end{array}$ \\
\hline Class & $\begin{array}{c}0.078^{* * *} \\
(0.030)\end{array}$ & $\begin{array}{l}0.168^{* *} \\
(0.078)\end{array}$ & $\begin{array}{l}-0.111 \\
(0.244)\end{array}$ & $\begin{array}{c}0.097 \\
(0.109)\end{array}$ & $\begin{array}{l}-0.114 \\
(0.107)\end{array}$ & $\begin{array}{l}-0.062 \\
(0.146)\end{array}$ \\
\hline Race & $\begin{array}{l}-0.063^{* *} \\
(0.030)\end{array}$ & $\begin{array}{c}0.119 \\
(0.073)\end{array}$ & $\begin{array}{c}-0.342 \\
(0.215)\end{array}$ & $\begin{array}{l}-0.070 \\
(0.122)\end{array}$ & $\begin{array}{c}0.014 \\
(0.100)\end{array}$ & $\begin{array}{l}-0.088 \\
(0.138)\end{array}$ \\
\hline Class+Race & $\begin{array}{l}-0.016 \\
(0.030)\end{array}$ & $\begin{array}{c}0.102 \\
(0.081)\end{array}$ & $\begin{array}{l}-0.306 \\
(0.240)\end{array}$ & $\begin{array}{c}0.113 \\
(0.112)\end{array}$ & $\begin{array}{c}0.048 \\
(0.098)\end{array}$ & $\begin{array}{l}-0.168 \\
(0.137)\end{array}$ \\
\hline Neutral Group Mean & 4.50 & 5.70 & 5.01 & 4.76 & 5.19 & 4.79 \\
\hline Cluster SEs? & $\checkmark$ & $\checkmark$ & $\checkmark$ & $\checkmark$ & $\checkmark$ & $\checkmark$ \\
\hline Weights? & $x$ & $x$ & $x$ & $x$ & $x$ & $x$ \\
\hline$N$ & 23,052 & 2,622 & 390 & 1,572 & 1,824 & 1,074 \\
\hline$R^{2}$ & 0.461 & 0.200 & 0.547 & 0.369 & 0.368 & 0.470 \\
\hline
\end{tabular}

Standard errors in parentheses

Pre-treatment covariates included in all regressions. Where noted, SEs are clustered at respondent level.

${ }^{*} p<0.10,{ }^{* *} p<0.05,{ }^{* * *} p<0.01$ 
Table A6: Treatment Effect on Policy Support by Partisanship and Race, No Weights

\begin{tabular}{lcccccc}
\hline & $(1)$ & $(2)$ & $(3)$ & $(4)$ & $(5)$ & $(6)$ \\
& White D & White R & White I & Non-White D & Non-White R & Non-White I \\
\hline Class & $0.132^{* * *}$ & 0.047 & 0.093 & 0.059 & 0.061 & 0.274 \\
& $(0.048)$ & $(0.059)$ & $(0.114)$ & $(0.068)$ & $(0.159)$ & $(0.231)$ \\
Race & 0.013 & -0.074 & -0.088 & 0.062 & -0.036 & -0.087 \\
& $(0.048)$ & $(0.062)$ & $(0.100)$ & $(0.065)$ & $(0.138)$ & $(0.322)$ \\
Class+Race & 0.057 & $-0.144^{* *}$ & 0.071 & $0.124^{*}$ & -0.020 & -0.282 \\
& $(0.048)$ & $(0.059)$ & $(0.109)$ & $(0.068)$ & $(0.142)$ & $(0.254)$ \\
\hline Neutral Group Mean & 5.73 & 3.37 & 4.34 & 5.84 & 3.74 & 4.84 \\
Cluster SEs? & $\checkmark$ & $\checkmark$ & $\checkmark$ & $\checkmark$ & $\checkmark$ & $\checkmark$ \\
Weights? & $\checkmark$ & $\checkmark$ & $\checkmark$ & $\checkmark$ & $\checkmark$ & $\checkmark$ \\
$N$ & 9,882 & 9,900 & 3,270 & 4,716 & 1,566 & 1,200 \\
$R^{2}$ & 0.185 & 0.319 & 0.241 & 0.136 & 0.402 & 0.231 \\
\hline
\end{tabular}

Standard errors in parentheses

Pre-treatment covariates included in all regressions.

Where noted, SEs are clustered at respondent level. This subgroup was not in the PAP.

${ }^{*} p<0.10,{ }^{* *} p<0.05,{ }^{* * *} p<0.01$

Table A7: Treatment Effect on Policy Support by Partisanship and Race

\begin{tabular}{lcccccc}
\hline & $(1)$ & $(2)$ & $(3)$ & $(4)$ & $(5)$ & $(6)$ \\
& White D & White R & White I & Non-White D & Non-White R & Non-White I \\
\hline Class & $0.066^{*}$ & 0.036 & $0.248^{* * *}$ & 0.066 & 0.035 & 0.084 \\
& $(0.038)$ & $(0.050)$ & $(0.085)$ & $(0.057)$ & $(0.129)$ & $(0.143)$ \\
Race & -0.044 & $-0.108^{* *}$ & 0.002 & 0.075 & -0.053 & -0.048 \\
& $(0.038)$ & $(0.049)$ & $(0.085)$ & $(0.055)$ & $(0.134)$ & $(0.131)$ \\
Class+Race & 0.021 & $-0.108^{* *}$ & 0.136 & $0.129^{* *}$ & -0.083 & -0.207 \\
& $(0.038)$ & $(0.049)$ & $(0.087)$ & $(0.056)$ & $(0.127)$ & $(0.135)$ \\
\hline Neutral Group Mean & 5.79 & 3.29 & 4.19 & 5.81 & 3.82 & 4.66 \\
Cluster SEs? & $\checkmark$ & $\checkmark$ & $\checkmark$ & $\checkmark$ & $\checkmark$ & $\checkmark$ \\
Weights? & $\boldsymbol{X}$ & $\boldsymbol{X}$ & $\boldsymbol{X}$ & $\boldsymbol{X}$ & $\boldsymbol{X}$ & $\boldsymbol{X}$ \\
$N$ & 9,882 & 9,900 & 3,270 & 4,716 & 1,566 & 1,200 \\
$R^{2}$ & 0.163 & 0.327 & 0.256 & 0.120 & 0.354 & 0.271 \\
\hline
\end{tabular}

Standard errors in parentheses

Pre-treatment covariates included in all regressions.

Where noted, SEs are clustered at respondent level. This subgroup was not in the PAP.

${ }^{*} p<0.10,{ }^{* *} p<0.05,{ }^{* * *} p<0.01$ 
Table A8: Treatment Effect on Secondary Outcomes

\begin{tabular}{lcccc}
\hline & $(1)$ & $(2)$ & $(3)$ & $(4)$ \\
& Fairness & Personal Benefit & Dem Support & GOP Support \\
\hline Class & $0.075^{* *}$ & $0.144^{* * *}$ & 0.012 & $0.084^{*}$ \\
& $(0.037)$ & $(0.039)$ & $(0.036)$ & $(0.048)$ \\
Race & -0.026 & 0.026 & -0.022 & -0.007 \\
& $(0.034)$ & $(0.040)$ & $(0.035)$ & $(0.051)$ \\
Class+Race & -0.007 & 0.049 & -0.038 & -0.036 \\
& $(0.039)$ & $(0.040)$ & $(0.037)$ & $(0.049)$ \\
\hline Neutral Group Mean & 4.59 & 3.82 & 5.75 & 3.12 \\
Cluster SEs? & $\checkmark$ & $\checkmark$ & $\checkmark$ & $\checkmark$ \\
Weights? & $\checkmark$ & $\checkmark$ & $\checkmark$ & $\checkmark$ \\
$N$ & 30,534 & 23,052 & 14,598 & 11,466 \\
$R^{2}$ & 0.426 & 0.365 & 0.091 & 0.308 \\
\hline
\end{tabular}

Standard errors in parentheses

Pre-treatment covariates included in all regressions.

Where noted, SEs are clustered at respondent level.

Fairness includes all respondents. Personal benefit includes non-Hispanic white respondents only.

Perception of Democratic (Republican) support is among Democratic (Republican) respondents.

${ }^{*} p<0.10,{ }^{* *} p<0.05,{ }^{* * *} p<0.01$ 
Table A9: Treatment Effect on Secondary Outcomes, No Weights

\begin{tabular}{lcccc}
\hline & $(1)$ & $(2)$ & $(3)$ & $(4)$ \\
& Fairness & Personal Benefit & Dem Support & GOP Support \\
\hline Class & $0.083^{* * *}$ & $0.138^{* * *}$ & -0.009 & $0.080^{* *}$ \\
& $(0.025)$ & $(0.032)$ & $(0.027)$ & $(0.040)$ \\
Race & -0.017 & -0.002 & -0.026 & -0.026 \\
& $(0.025)$ & $(0.033)$ & $(0.027)$ & $(0.040)$ \\
Class+Race & 0.027 & $0.070^{* *}$ & -0.026 & -0.018 \\
& $(0.025)$ & $(0.033)$ & $(0.027)$ & $(0.040)$ \\
\hline Neutral Group Mean & 4.52 & 3.79 & 5.76 & 3.02 \\
Cluster SEs? & $\checkmark$ & $\checkmark$ & $\checkmark$ & $\checkmark$ \\
Weights? & $\boldsymbol{X}$ & $\boldsymbol{X}$ & $\boldsymbol{X}$ & $\boldsymbol{X}$ \\
$N$ & 30,534 & 23,052 & 14,598 & 11,466 \\
$R^{2}$ & 0.443 & 0.374 & 0.083 & 0.292 \\
\hline
\end{tabular}

Standard errors in parentheses

Pre-treatment covariates included in all regressions.

Where noted, SEs are clustered at respondent level.

Fairness includes all respondents. Personal benefit includes non-Hispanic white respondents only.

Perception of Democratic (Republican) support is among Democratic (Republican) respondents.

${ }^{*} p<0.10,{ }^{* *} p<0.05,{ }^{* * *} p<0.01$ 
Table A10: Treatment Effect on Policy Support by White Guilt (Terciles)

\begin{tabular}{lcccccc}
\hline & $\begin{array}{c}(1) \\
\text { Least Guilt }\end{array}$ & $\begin{array}{c}(2) \\
\text { Least Guilt }\end{array}$ & $\begin{array}{c}(3) \\
\text { Middle Guilt }\end{array}$ & $\begin{array}{c}(4) \\
\text { Middle Guilt }\end{array}$ & $\begin{array}{c}(5) \\
\text { Most Guilt }\end{array}$ & $\begin{array}{c}(6) \\
\text { Most Guilt }\end{array}$ \\
\hline Class & 0.021 & 0.037 & $0.172^{* * *}$ & $0.176^{* * *}$ & 0.007 & 0.048 \\
& $(0.051)$ & $(0.065)$ & $(0.052)$ & $(0.066)$ & $(0.044)$ & $(0.054)$ \\
Race & $-0.133^{* * *}$ & $-0.131^{* *}$ & 0.030 & 0.054 & $-0.083^{*}$ & -0.003 \\
& $(0.050)$ & $(0.061)$ & $(0.051)$ & $(0.066)$ & $(0.046)$ & $(0.063)$ \\
Class+Race & $-0.104^{* *}$ & $-0.104^{*}$ & 0.059 & 0.007 & -0.005 & 0.048 \\
& $(0.050)$ & $(0.062)$ & $(0.053)$ & $(0.064)$ & $(0.043)$ & $(0.058)$ \\
\hline Neutral Group Mean & 3.39 & 3.42 & 4.68 & 4.65 & 5.94 & 5.84 \\
Cluster SEs? & $\checkmark$ & $\checkmark$ & $\checkmark$ & $\checkmark$ & $\checkmark$ & $\checkmark$ \\
Weights? & $\boldsymbol{X}$ & $\checkmark$ & $\boldsymbol{X}$ & $\checkmark$ & $\boldsymbol{X}$ & $\checkmark$ \\
$N$ & 9,270 & 9,270 & 7,248 & 7,248 & 6,534 & 6,534 \\
$R^{2}$ & 0.393 & 0.382 & 0.308 & 0.289 & 0.187 & 0.187 \\
\hline
\end{tabular}

Standard errors in parentheses

Pre-treatment covariates included in all regressions.

Where noted, SEs are clustered at respondent level.

${ }^{*} p<0.10,{ }^{* *} p<0.05,{ }^{* * *} p<0.01$

Table A11: Treatment Effect on Policy Support by Class, No Weights

\begin{tabular}{lcccc}
\hline & $(1)$ & $(2)$ & $(3)$ & $(4)$ \\
& Lower Class & Working Class & Middle Class & Upper Class \\
\hline Class & 0.094 & 0.061 & $0.089^{* *}$ & 0.075 \\
& $(0.082)$ & $(0.044)$ & $(0.037)$ & $(0.106)$ \\
Race & -0.051 & -0.045 & -0.038 & -0.033 \\
& $(0.083)$ & $(0.044)$ & $(0.037)$ & $(0.088)$ \\
Class+Race & -0.023 & -0.057 & 0.048 & 0.011 \\
& $(0.080)$ & $(0.044)$ & $(0.037)$ & $(0.106)$ \\
\hline Neutral Group Mean & 4.95 & 4.73 & 4.45 & 5.58 \\
Cluster SEs? & $\checkmark$ & $\checkmark$ & $\checkmark$ & $\checkmark$ \\
Weights? & $\boldsymbol{X}$ & $\boldsymbol{X}$ & $\boldsymbol{X}$ & $\boldsymbol{X}$ \\
$N$ & 3,510 & 10,746 & 14,646 & 1,632 \\
$R^{2}$ & 0.346 & 0.424 & 0.487 & 0.511 \\
\hline
\end{tabular}

Standard errors in parentheses

Pre-treatment covariates included in all regressions.

Where noted, SEs are clustered at respondent level.

${ }^{*} p<0.10,{ }^{* *} p<0.05,{ }^{* * *} p<0.01$ 
Table A12: Treatment Effect on Policy Support by Class

\begin{tabular}{lcccc}
\hline & $(1)$ & $(2)$ & $(3)$ & $(4)$ \\
& Lower Class & Working Class & Middle Class & Upper Class \\
\hline Class & 0.082 & 0.073 & $0.106^{* *}$ & 0.120 \\
& $(0.087)$ & $(0.054)$ & $(0.051)$ & $(0.149)$ \\
Race & -0.102 & 0.002 & -0.012 & 0.017 \\
& $(0.166)$ & $(0.051)$ & $(0.048)$ & $(0.124)$ \\
Class+Race & 0.006 & -0.075 & 0.051 & -0.066 \\
& $(0.082)$ & $(0.054)$ & $(0.049)$ & $(0.242)$ \\
\hline Neutral Group Mean & 4.96 & 4.82 & 4.47 & 5.50 \\
Cluster SEs? & $\checkmark$ & $\checkmark$ & $\checkmark$ & $\checkmark$ \\
Weights? & $\checkmark$ & $\checkmark$ & $\checkmark$ & $\checkmark$ \\
$N$ & 3,510 & 10,746 & 14,646 & 1,632 \\
$R^{2}$ & 0.330 & 0.416 & 0.482 & 0.449 \\
\hline Standar & & & &
\end{tabular}

Standard errors in parentheses

Pre-treatment covariates included in all regressions.

Where noted, SEs are clustered at respondent level.

${ }^{*} p<0.10,{ }^{* *} p<0.05,{ }^{* * *} p<0.01$ 
Figure A1: Treatment Effect by Issue

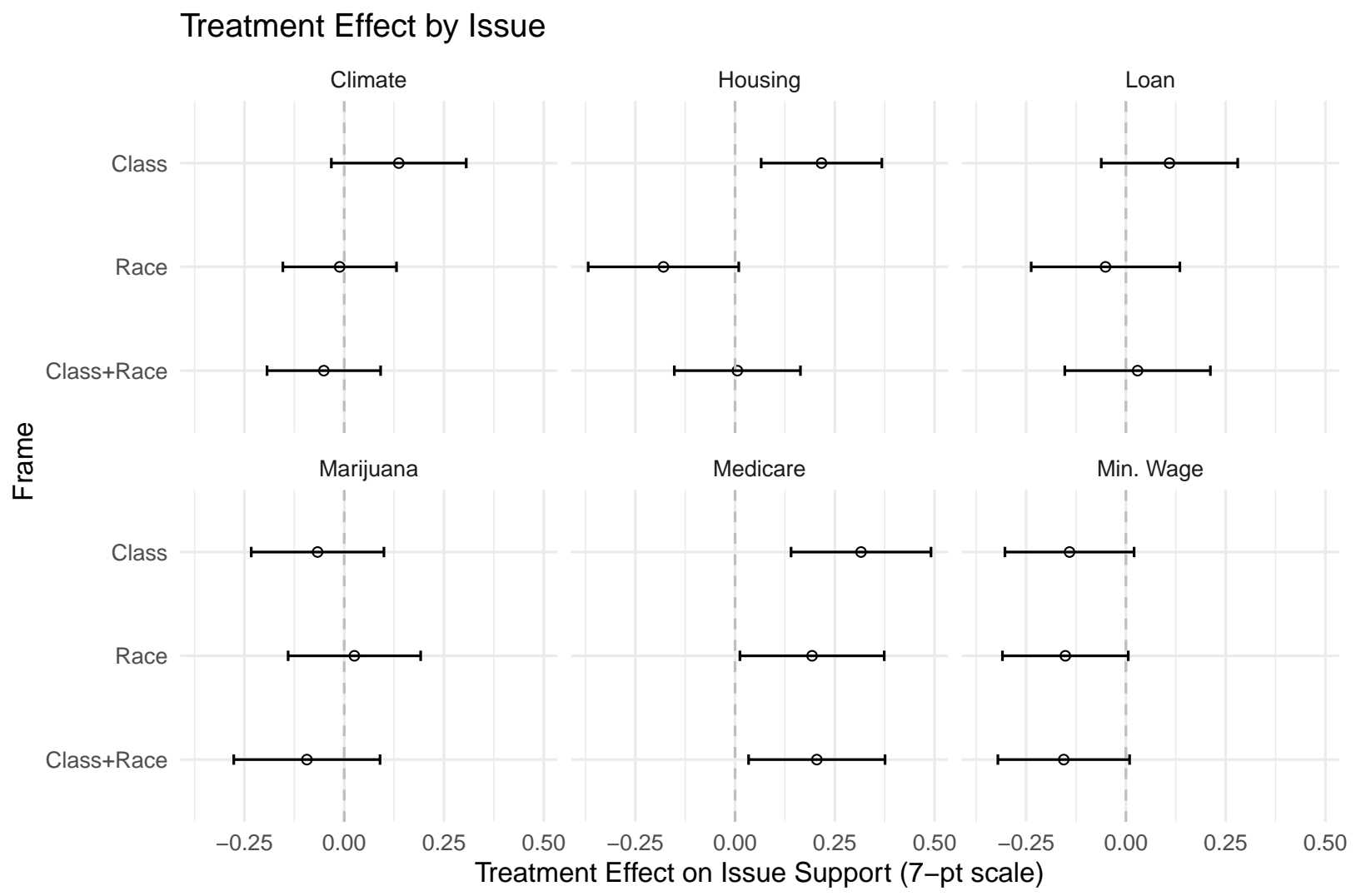

Notes: Error bars denote $95 \%$ confidence intervals. 